\title{
ПІДСТАВИ НАБУТТЯ СЕРВІТУТНИХ ПРАВ
}

Ільків О. В.

Cтаттю присвячено дослідженню підстав набуття сервітутних прав. Серед усіх елементів системи обмежених речових прав свою особливу роль і місце посідає сервітуm. Через недостатню законодавчу регламентацію і високу значимість для цілісності системи обмежених речових прав сервітут активно обговорюється в науковому колі. Відповідно до принципів рівності, автономії волі і свободи договору учасників цивільного обороту обґрунтовується необхідність надання особам, яким на праві оренди належить нерухоме майно незалежно від його форми власності, права бути суб'єктами сервітутних відносин. Приділено увагу умовам набуття речового (майнового) права відказоодержувачем на основі заповідального відказу, зокрема, прийняття спадкоємцем за заповітом спадщини. Заповідальний відказ втрачає силу у разі відмови спадкоємия від прийняття спадщини, усунення від спадкування, визнання заповіту недійсним, неприйняття спадщини. Зазначення в заповіті предмета заповідального відказу неможливо трактувати як підставу для встановлення сервітутних відносин, а необхідно розглядати як елемент юридичного складу для виникнення сервітутного права. Варто відзначити, що слід розрізняти право вимоги як майнове право відказоодержувача до спадкоємця про надання права користування певним майном, яке входить до спадкової маси та право сервітуту, яке встановлюється в заповіті щодо земельної ділянки, інших природних ресурсів або іншого нерухомого майна.

У статті автор висвітлює позицію, що спадкодавець має право встановити у заповіті сервітут щодо земельної ділянки, інших природних ресурсів або іншого нерухомого майна для задоволення потреб інших осіб, які не можуть бути задоволені іншим способом.

У ході проведеного дослідження автором пропонується здійснити поправки в низку нормативно-правових актів щодо підстав набуття сервітутів із заповіту, земельних сервітутів та житлових сервітутів.

Ключові слова: сервітут, набуття сервітутних прав, заповідальний відказ, земельний сервітут, житловий сервітут.

Ilkiv 0 . V. Grounds for acquiring servitude rights

The article is devoted to the study of the grounds for acquiring easement rights. Among all the elements

(с) Ільків О. В., 2020 of the system of limited property rights, an easement occupies a special role and place. Due to insufficient legislation and high importance for the integrity of the system of limited property rights, the easement is actively discussed. In accordance with the principles of equality, autonomy of freedom of participants contract in civil turnover, the need to grant persons who own real estate on the right of lease, regardless of its form of ownership, the right to be subjects of servitude.

Attention is paid to the conditions of acquisition of the property (property) right by the testator on the basis of the testamentary disclaimer, in particular acceptance by the heir of the testamentary inheritance. A testamentary disclaimer loses its force in the event of the heir's refusal to accept the inheritance, removal from the inheritance, recognition of the will as invalid, non-acceptance of the inheritance. The indication in the will of the subject of the testamentary disclaimer cannot be interpreted as a basis for establishing servitude relations, but must be considered as an element of the legal structure for the emergence of servitude law. It should be noted that a distinction should be made between the right of claim as the testator's property right to the heir to grant the right to use certain property, which is part of the estate and the easement, which is established in the will for land, other natural resources or other real estate.

In the article, the author highlights the position that the testator has the right to establish in the will an easement for land, other natural resources or other real estate to meet the needs of others who cannot be satisfied otherwise.

In the course of the study, the author proposes to amend a number of regulations on the grounds for acquiring easements from wills, land easements and housing easements.

Key words: easement, acquisition of easement rights, testamentary disclaimer, land easement, housing easement.

Постановка проблеми та іï актуальність. Інститут сервітутів виник ще у давньоримському праві та пройшов доволі довгий шлях еволюції та вдосконалення. Протягом цього шляху змінювалися та доповнювалися підстави набуття сервітутів. У доктрині приватного права надається вагоме значення факту набуття сервітутів, оскільки це стосується інтересів власника речі, яка $\epsilon$ предметом сервітуту. У сучасній правовій 
науці дослідження підстав набуття сервітутів $€$ не зовсім цілісне. Сервітутні договори нині укладаються доволі часто, саме тому актуальним є дослідження підстав набуття сервітутних прав.

Аналіз останніх досліджень і публікацій. Вагомий внесок щодо вивчення сервітутів зроблено українськими та зарубіжними вченими, серед яких - В. Луць, А. Підопригора, А. Бірюков, Є. Харитонов, П. Кулинич, Б. Тищик, А. Сосніна, І. Косарєв, В. Ефимов, Л. Кофанов, А. Хвостов та інші. Без цих фундаментальних досліджень досі не може обійтися жодна наукова праця у вибраній сфері. Проте потребує детальнішого вивчення питання набуття сервітутних прав.

Метою статті $\epsilon$ дослідження підстав набуття сервітутних прав у цивільно-правовому аспекті.

Виклад основного матеріалу. Сервітутні права в цивільному праві України отримали нормативне закріплення в Цивільному кодексі України (далі - ЦК України) ще у 2003 році (Глава 32 ЦК України) [1]. Структура системи сервітутів майже не зазнала змін з часів Стародавнього Риму, де виникнення прав на чужі речі було зумовлене необхідністю задоволення інтересів інших осіб шляхом обмеження сукупності правомочностей власника стосовно належних йому речей. А тому відбулась рецепція положень римського права у сьогодення, відповідно, остання $\epsilon$ схожою до всієї континентальної системи речових прав.

Як нам видається, сервітутні права, тобто права, які закріплюють належність певних правомочностей окремим особам щодо речей, що $\epsilon$ об'єктами права власності інших осіб, появилися в механізмі правового регулювання разом із правом приватної власності. Тому вважається, що сервітут визначає обсяг правомочностей уповноваженого суб'єкта щодо певного майна, що належить на праві власності іншій особі. Таким чином, сервітут не позбавляє власника речі суб'єктивного права володіти, користуватись та розпоряджатись нею, а лише обтяжує право власності й відповідно перелічені правомочності.

Зазначені обтяження права власності для власника та відповідно обмежені сервітутні права для уповноваженої особи можуть мати як об'єктні, так і суб'єктні прив'язки. Про що йдеться спробуємо пояснити на прикладах. Правомочності, які становлять зміст сервітуту, виникають і припиняються залежно від правового статусу особи, яка володіє сервітутними правами у випадку особистого сервітуту. Так, житловий сервітут завжди пов'язується зі статусом члена сім'ї як власника житлової нерухомості. При цьому особисті серві- тутні права не можуть бути передані іншій особі, а також вони не можуть переходити іншим особам як шляхом правонаступництва, так і за договорами з володільцем сервітуту.

Отже, сервітутні відносини, об'єктом яких $\epsilon$ певна нерухомість, існують незалежно від суб'єкта сервітутних прав. Наприклад, зміна власника сусідньої земельної ділянки, який мав право проходу (проїзду) через суміжну земельну ділянку, $є$ підставою для набуття сервітутних прав новим власником ділянки. Адже, таким чином, зазнає змін правовий механізм набуття сервітутних прав. На наш погляд, якщо попередній власник сервітутного права набув його на підставі цивільно-правового договору, яким було надано сервітут, то він припиняється. 3 новим власником сусідньої ділянки сервітутне право може бути набуте шляхом укладення нового договору. Однак у разі придбання земельної ділянки новим власником, він має первинне право на сервітут на підставі закону, якщо дотримані передбачені законодавством передумови виникнення сервітутних відносин. У такому разі сервітутне право виникає у зв'язку з об'єктом права власності.

Разом із тим підставою для виникнення сервітуту $\epsilon$ також заповіт (ст. 402 ЦК України) [1]. У цивільному праві заповітом називають особисте розпорядження фізичної особи щодо спадщини на випадок смерті. До складу спадщини входять усі права та обов'язки, що належали спадкодавцеві на момент відкриття спадщини і не припиняються внаслідок його смерті.

Крім того, як уже нами наголошувалось, сервітутні права мають свої особливості залежно від управненої особи. Особисті сервітутні права не можуть входити до складу спадщини. Тому вважаємо, що ст. 1219 ЦК України необхідно доповнити п. 6 такого змісту:

«6) права спадкодавця передбачені особистим сервітутом».

Через перелічені обставини назва ст. 402 ЦК України «Встановлення сервітуту» законодавцем $\epsilon$ не зовсім доречною, бо, на наш погляд, вона має називатися так: «Підстави виникнення сервітуту як речового права». А тому серед інших юридичних фактів сервітут може бути встановлений заповітом.

Виходячи з правової природи заповіту як розпорядчого акта на випадок смерті, можна констатувати, що спадкодавець може встановити сервітут лише на майно, яке входить до складу спадщини і яким він володіє на праві власності. Однак суб'єктом речового права у вигляді 
сервітуту буде не спадкоємець (спадкоємці), а третя особа. У такому разі йдеться про заповідальний відказ. Вважається, що предметом заповідального відказу може бути передання відказоодержувачеві у власність або за іншим речовим правом майнового права або речі, що входить або не входить до складу спадщини. Отже, сервітут може виникнути на підставі заповідального відказу. На спадкоємця, до якого переходить житловий будинок, квартира або інше рухоме чи нерухоме майно, заповідач має право покласти обов'язок надати іншій особі право користування ними. Право користування житловим будинком, квартирою або іншим нерухомим чи рухомим майном зберігає чинність у разі наступної зміни їх власника.

Таким чином, за заповідальним відказом до відказоодержувача може перейти сервітутне право, що має особистий характер. Право користування житловим будинком, квартирою або іншим нерухомим чи рухомим майном є суб'єктивним речовим правом управомоченої особи. 3 іншого боку, предмет заповідального відказу у формі речового права є обтяженням для власника - спадкоємця. А відказоодержувач має право вимоги до спадкоємця з часу відкриття спадщини.

У ст. 1246 ЦК України окремо визначена можливість встановлення сервітуту у заповіті. Згідно 3 названою статтею, спадкоємець має право встановити у заповіті сервітут щодо земельної ділянки, інших природних ресурсів або іншого нерухомого майна для задоволення потреб інших осіб. Ця норма певною мірою дублює положення статті 1238 ЦК України, виокремлюючи сервітут як речове право у самостійний об'єкт правовідношення [1].

Одночасно зміст зазначених статей має певні відмінності. У ст. 1238 ЦК України вказується конкретна особа відказоодержувача, якому надається суб'єктивне право вимоги про надання сервітуту до спадкоємця. Таким чином, заповідальний відказ $є$ разом із заповітом юридичним фактом для виникнення правовідношення між спадкоємцем та відказоодержувачем, змістом якого є обов'язок спадкодавця надати відказоодержувачеві право користування майном, що перейшло у його власність на підставі заповіту.

Для набуття речового (майнового) права відказоодержувачем необхідною умовою $\epsilon$ прийняття спадкоємцем за заповітом спадщини. У разі його відмови від прийняття спадщини, усунення від спадкування, визнання заповіту недійсним, неприйняття спадщини заповідальний відказ втрачає силу.
Таким чином, потенційний відказоодержувач не має можливості висунути вимогу до спадкоємця за заповітом, на якого спадкодавець поклав у заповіті як розпорядчому правочині обов'язок надати відказоодержувачу конкретне речове право, в тому числі сервітут. Отже, як нам видається, зазначення у заповіті предмета заповідального відказу неможливо трактувати як підставу для встановлення сервітутних відносин, а необхідно розглядати як елемент юридичного складу для виникнення сервітутного права.

Аналогічна ситуація склалася зі встановленням сервітуту у заповіті. У такому разі спадкодавець покладає на спадкоємця (спадкоємців) у заповіті обов'язок (обтяження) у вигляді сервітуту щодо земельної ділянки, інших природних ресурсів або іншого нерухомого майна для задоволення потреб інших осіб [1].

Підкреслюється, що в дефініції ст. 1246 ЦК України вже йдеться про конкретне речове право сервітут, не вказуються особи, які мають право на сервітут. У коментованій статті уточнюється, що власне спадкодавець має право встановити у заповіті сервітут щодо земельної ділянки, інших природних ресурсів або іншого нерухомого майна для задоволення потреб інших осіб, не вказуючи, що останні мають право вимоги до спадкоємця з часу відкриття спадщини як у разі заповідального відказу.

Охарактеризувавши написане, варто відзначити, що слід розрізняти таке:

право вимоги як майнове право відказоодержувача до спадкоємця про надання права користування певним майном, яке входить до спадкової маси;

право сервітуту, яке встановлюється у заповіті щодо земельної ділянки, інших природних ресурсів або іншого нерухомого майна.

Якщо предметом заповідального відказу охоплюються як рухомі, так і нерухомі речі, то об'єктом права вимоги може бути лише нерухомість. Саме тому право вимоги не можна ототожнювати із сервітутом. Принагідно нагадаємо, що сервітут визначає обсяг прав щодо користування особою чужим майном і не підлягає відчуженню. Останнє слід розуміти, що саме право користування чужим майно не може бути самостійним предметом договорів (правочинів) поза зв'язком із нерухомістю, яку сервітут обтяжує. При цьому сервітут не позбавляє власника майна, щодо якого він встановлений, права володіння, користування та розпорядження цим майном. 
У ст. 1246 ЦК України передбачено, що спадкодавець має право встановити у заповіті сервітут щодо земельної ділянки інших природних ресурсів або іншого нерухомого майна для задоволення потреб інших осіб. При цьому використовується абстрактний термін «інших осіб». 3 нашої точки зору, необхідно з'ясувати питання щодо конкретизації цих осіб у заповіті. Іншими словами, слід зазначити, чи може спадкодавець покласти обтяження на спадкоємця у вигляді сервітуту, не вказуючи конкретних осіб, які мають право користування об'єктом нерухомості, що належить до спадкової маси.

Згідно зі ст. 1238 цК України, предметом заповідального відказу може бути будь-яке речове право майнового характеру. Таким чином, на спадкоємця, до якого переходить рухоме чи нерухоме майно, заповідач має право покласти обов'язок надати іншій особі право користування ними. Встановлене право користування житловим будинком, квартирою або іншим нерухомим чи рухомим майном зберігає чинність і у разі наступної зміни їх власника.

Звідси випливає, що сервітут може бути встановлений у заповіті для задоволення потреб осіб, які згідно зі ст. 401 цК України не можуть бути задоволені іншим способом. Право користування чужим майном може бути встановлене щодо будівель, споруд чи іншого нерухомого майна. Право користування чужою земельною ділянкою або іншим нерухомим майном полягає у можливості проходу (проїзду) через чужу земельну ділянку, прокладання чи експлуатації ліній електропередач, зв'язку і трубопроводів, забезпечення водопостачанням та водовідведенням, якщо іншим чином потреби користувача не можуть бути задоволені.

Отже, право сервітуту не можна надати будьякій особі. Надання права користування річчю будь-якій особі слід трактувати як розпорядження майновим (речовим) правом. Таке розпорядження може здійснити власник на підставі договору (правочину), в тому числі розпорядчому правочині на випадок смерті - заповіті. Майнове право в такому разі не набуває правового режиму сервітуту.

Як відомо, книга третя цК України має назву «Право власності та інші речові права» [1]. Поняттям «інші речові права» охоплюються різні види речових прав. Критерієм ї виокремлення $\epsilon$ те, що правомочності, визначені законом або договором, належать особі, яка не $\epsilon$ власником речі.

Зважаючи на зазначене, варто звернути увагу на те, що речові права наділяють особу лише пев- ними правомочностями чи однією із них. Залежно від змісту речового права суб'єкт матиме можливість здійснити конкретні правомочності. Тому наявність можливості невласником реалізувати суб'єктивне речове право $є$ обтяженням для власника. Обов'язок надати можливість здійснення майнового права іншою особою заповідач може накласти на спадкоємця. Але це не обов'язково може бути сервітут.

У такому разі акт розпорядження з боку спадкодавця можливий без згоди потенційного власника - спадкоємця. Останній може прийняти спадщину або відмовитися від неї. Майнове право іншої особи $\epsilon$ обтяженням для власника успадкованого майна. Певні речові права можуть набувати також спадкоємці. У Постанові Пленуму Верховного Суду України від 30 травня 2008 року «Про судову практику у справах про спадкування» [2] визначено, що спадкоємці, які успадкували нерухоме майно (його частину), набувають права на земельну ділянку, на якій розміщено це майно, та на частину ділянки, яка $\epsilon$ необхідною для його обслуговування, незалежно від змісту заповіту навіть у разі, якщо спадкодавець заповів усю земельну ділянку або їі частину іншим особам, які не успадкували таке нерухоме майно.

Таким чином, спадкодавець має право встановити у заповіті сервітут щодо земельної ділянки, інших природних ресурсів або іншого нерухомого майна для задоволення потреб інших осіб. Однак зазначені потреби повинні мати об'єктивний характер та відповідати вимогам, передбаченим у ст.ст. 401, 402 ЦК України. Тому ст. 1248 ЦК України необхідно, вважаємо, викласти в такій редакції: «Спадкодавець має право встановити у заповіті сервітут щодо земельної ділянки, інших природних ресурсів або іншого нерухомого майна для задоволення потреб інших осіб, які не можуть бути задоволені іншим способом». Надання майнових (речових) прав у заповіті на нерухоме і рухоме майно особам, які не відповідають критеріям осіб, потреби яких не можуть бути задоволені іншим способом, $\epsilon$ предметом заповідального відказу і регулюватимуться ст. 1238 ЦК України.

Як свідчить практика, найчастіше об'єктом сервітутних прав $\epsilon$ земельні ділянки. Згідно з положеннями Земельного кодексу України (далі - ЗК України), право земельного сервітуту - це право власника або землекористувача земельної ділянки на обмежене платне або безоплатне користування чужою земельною ділянкою (ділянками) [3]. Як зазначено в ст. 401 ЗК України, підставою виникнення земельного сервітуту $\epsilon$ відсутність у особи 
можливості задовольнити свої потреби іншим способом, крім встановлення права користування чужим майном. Подібний підхід задекларований як у ЦК України, так і в ЗК України.

Такими самими критеріями керуються суди під час розгляду спірних ситуацій з набуття права на сервітут. Так, у Постанові пленуму Вищого спеціалізованого суду України з розгляду цивільних і кримінальних справ від 7 лютого 2014 року «Про судову практику в справах про захист права власності та інших речових прав» визначено, що умовою встановлення сервітуту $\epsilon$ неможливість повноцінного використання своєї земельної ділянки без обтяження сервітутом чужої земельної ділянки [4].

Таким чином, правозастосовча практика виходить 3 позицій, що господарське використання своєї земельної ділянки без обтяження сервітутом ділянки, що належить на праві власності іншій особі, $є$ об'єктивною підставою для встановлення земельного сервітуту. Це правило $є$ актуальним і для встановлення сервітуту на підставі договору.

Об'єктивною умовою змісту такого договору $\epsilon$ наявність існуючої потреби сервітуту з метою нормального використання власної земельної ділянки. А іншим чином, окрім одержання сервітутного права, це здійснити не можна.

Важливо наголосити, що на правовий режим лісового сервітуту поширюються положення речового права на чуже майно, встановлені в ЦК України та ЗК України поряд із спеціальними нормами Лісового кодексу України [5]. В основі лісового сервітуту лежить потреба користування земельними лісовими ділянками. Так само це пов'язується з необхідністю задоволення потреби у користуванні, якщо іншим способом реалізація $\epsilon$ неможливою. При цьому застосовуються інші спеціальні закони, зокрема Закон України «Про охорону навколишнього природного середовища» [6].

Окрім указаного, на наш погляд, слід зауважити про наявність певних особливостей регулювання, пов'язаних із житловим сервітутом. Сутність житлового сервітуту полягає у задоволенні житлових потреб осіб, які не $\epsilon$ власниками житла. Житлові сервітути обтяжують право власності. Йдеться про право користування та володіння. Це пов'язано із тим, що члени сім’ї власника житла, які проживають разом із ним, мають право користування житловим приміщенням згідно зі ст. 405 цК України [1].

ЦК України не містить визначення члена сім'ї як власника житла. Перелік членів сім'ї наймача житла вказується в Житловому кодексі Української РСР [7]. До них належить подружжя, діти, батьки та інші особи, які разом із ним проживають та ведуть спільне господарство. Однак зазначений перелік стосується житлових відносин з найму житла в будинках громадського, державного та комунального житлового фонду.

До того ж нормами ЦК України регулюються відносини з найму житла приватної форми власності. Відповідно до зазначених норм разом з наймачем можуть проживати інші особи, вказані в договорі найму житла. Зазначені різновиди відносин належать до зобов'язальних, а не речових.

Таким чином, визначальним критерієм для виникнення житлового сервітуту $\epsilon$ факт сімейних відносин та постійне проживання на житловій площі, яка належить на праві власності іншій особі. Насамперед неодмінно варто встановити належність особи до сім'ї власника житла. При цьому родинні зв'язки не мають правового значення, адже дочка (син) можуть мати свої сім'ї та проживати окремо. Це ж саме стосується батьків, і навіть одного з подружжя, що проживає окремо або перебуває у сепарації.

Сутність житлового сервітуту полягає у можливості користування житлом незалежно від волі власника цього житла. У цьому разі речове право на житло не обмежується лише житловим сервітутом, який дає право на проживання. Зміст речового права на чуже житло становлять повноваження володіння (зокрема, в праві господарського відання, права оперативного управління житлом) або права на звернення стягнення (у забезпечувальних речових правах на житло) чи у вигляді права користування (в усіх інших видах речових прав на чуже житло) [8, с. 3].

Взагалі будь-яка особа незалежно від родинних відносин з власником житла, яка належить до числа членів сім'ї та проживає в житловому приміщенні, може мати житловий сервітут на підставі закону. Як наслідок, правове значення матиме належність до сім'ї власника житла та проживання разом із ним.

Окрім зазначеного, гадаємо, що дефініція ст. 405 ЦК України потребує уточнення. Насамперед зазначене стосується визначення поняття «місце проживання». Відповідно до ст. 29 ЦК України місцем проживання фізичної особи є житло, в якому вона проживає постійно або тимчасово. До членів сім'ї наймача, згідно з ч. 2 ст. 64 Житлового кодексу Української РСР, належить дружина наймача, їхні діти і батьки [7]. Членами сім'ї наймача може бути визнано й інших осіб, якщо вони постійно проживають разом із наймачем і ведуть з ним спільне господарство. 
Коментована дефініція стосується відносин найму житла, тобто зобов'язальних відносин. У цьому контексті члени сім’ї наймача, які проживають разом із ним, користуються нарівні з наймачем усіма правами та несуть обов'язки, що виникають з договору найму житлового приміщення. При цьому підкреслюється, що до членів сім’ї, які мають право на користування житловим приміщенням, належать лише особи, що постійно проживають з наймачем. А положення ст. 405 ЦК України передбачають право членів сім'ї власника житла на користування цим житлом, а тому підкреслюють, що це право мають лише члени сім'ї власника житла, які проживають разом з ним. Іншими словами, не зауважується ознака постійності чи тимчасовості проживання.

Відповідно до ч. 1 ст. 29 ЦК України місцем проживання фізичної особи є житловий будинок, квартира, інше приміщення, придатне для проживання в ньому (гуртожиток, готель тощо), у відповідному населеному пункті, в якому фізична особа проживає постійно, переважно або тимчасово. Інакше кажучи, тимчасовість чи постійність проживання не мають правового значення для визначення місця проживання [1].

Звісно, виникнення права користування житлом пов'язується не лише з фактичним проживанням на житловій площі, а й з правовою підставою набуття права користування. Так, тимчасові жильці не набувають права користування житлом. I відповідно, не можуть бути суб'єктами житлового сервітуту.

Місце проживання має вагоме значення для цивільно-правових відносин. Але законодавець не завжди конкретизує поняття місця проживання в часовому вимірі з погляду постійного чи тимчасового проживання в певному місці. При цьому в ч. 6 ст. 29 ЦК України передбачається, що фізична особа може мати кілька місць проживання [1]. Водночас приписами Закону України «Про свободу пересування та вільний вибір місця проживання в Україні» встановлено, що фізична особа може мати лише одне місце проживання, за яким вона повинна бути зареєстрована [9].

Названий закон регулює сферу публічно-правових відносин, але може мати й цивільно-правові наслідки. Згідно зі ст. 3 Закону України «Про свободу пересування та вільний вибір місця проживання в Україні», під місцем проживання розуміють житловий об'єкт, розташований на території адміністративно-територіальної одиниці, де особа проживає строком понад шість місяців на рік [9]. У цьому ж законі міститься визначення поняття «місце перебування», яким називають адміністративно-територіальну одиницю, на території якої особа проживає менше шести місяців на рік.

Натомість приписи ЦК України місце проживання прив'язують до житлового приміщення, придатного для проживання. При цьому місце проживання може бути як постійним, так і тимчасовим.

Для виникнення житлового сервітуту значення має постійне місце проживання. Презумпцією буде місце реєстрації фізичної особи, яке може бути лише одне - там, де особа зареєстрована. Вказане не означає, що фактичне місце проживання може бути іншим. У такому разі необхідно встановити юридичний факт спільного проживання разом з власником. Місцем проживання фізичної особи віком від десяти до чотирнадцяти років $є$ місце проживання їі батьків (усиновлювачів) або одного з них, з яким вона проживає, опікуна або місцезнаходження навчального закладу чи закладу охорони здоров'я тощо, в якому вона проживає, якщо інше місце проживання не встановлено за згодою між дитиною та батьками (усиновлювачами, опікуном) або організацією, яка виконує щодо неї функції опікуна. У разі спору місце проживання фізичної особи віком від десяти до чотирнадцяти років визначається органом опіки та піклування або судом.

Місцем проживання фізичної особи, яка не досягла десяти років, $\epsilon$ місце проживання їі батьків (усиновлювачів) або одного з них, з ким вона проживає, опікуна або місцезнаходження навчального закладу чи закладу охорони здоров'я, у якому вона проживає. Місцем проживання недієздатної особи є місце проживання їі опікуна або місцезнаходження відповідної організації, яка виконує щодо неї функції опікуна [1].

Хоча фізична особа може мати кілька місць проживання, для набуття житлового сервітуту слід визначити місце іï постійного проживання. Якщо це місце співпадає з місцем проживання власника житла, то йдеться про речові відносини.

Проживання в іншому житловому приміщенні, яке не належить на праві власності суб'єкту житлових відносин, не може вважатися підставою виникнення сервітуту. Для набуття житлового сервітуту, як зазначалося, необхідними умовами $\epsilon$ спільне проживання з власником житла як члена його сім'ї. Якщо місцем проживання власника житла $є$ різні житлові приміщення, які належать йому на праві власності, і в одному з цих приміщень проживають члени його сім'ї разом із ним, то вони матимуть право користування житлом за 
умови, що це житло є їхнім постійним місцем проживання.

Тому, зважаючи на наведені вище обставини, на наш погляд, ч. 1 ст. 405 ЦК України доцільно викласти в такій редакції: «Члени сім’ї власника житла, які постійно чи тимчасово проживають разом із ним, мають право на користування цим житлом відповідно до закону».

Право користування житлом є особистим сервітутом, що підтверджує належність до членів сім'і власника і факт проживання разом із ним. Підтвердженням належності до членів сім'ї можуть бути родинні відносини або ведення спільного господарства на основі взаємної домовленості.

Особливість житлового сервітуту полягає в тому, що його суб'єкт не має у власності житла. В нього виникає лише право користування житлом. Це право має особистий характер. Житловий сервітут $є$ правом безоплатного користування житлом, якщо домовленістю з власником не передбачено інше. Але це не звільняє суб'єкта житлового сервітуту від обов'язку сплачувати комунальні послуги.

Житловий сервітут виникає у члена сім'ї власника, якщо він вселився на законній підставі зі згоди власника житла. Це може бути як юридичний факт, пов'язаний з реєстрацією місця проживання члена сім'ї, так і фактичне користування житлом разом із власником житла за умови відсутності заперечень з його боку. У разі спору необхідно цю обставину встановлювати у справах окремого провадження як факт, що має юридичне значення.

ЦК України вказує лише на одну підставу припинення житлового сервітуту - відсутність члена сім'ї власника понад 1 рік. Зі змісту дефініції ст. 405 ЦК України випливає, що право користування житловим сервітутом мають лише члени сім’ї власника житла.

Припинення сімейних відносин призводить також і до припинення житлового сервітуту, який має особистий характер. Однак питання порядку припинення права користування в такому разі не врегульоване чинним законодавством.

Припинення сімейних відносин $є$ правоприпиняючою обставиною для житлового сервітуту. Розірвання шлюбу свідчить про припинення сімейних відносин між подружжям і відповідно житлового сервітуту в одного із них. Але це не уможливлює можливість користування житлом у рамках зобов'язальних відносин найму житла.

Висновки. Сервітут може набуватися як за волею власника, так і проти його волі, а також після його смерті з огляду на присутність юридичних фактів. В юридичній літературі традиційно розмежовують поняття підстави набуття прав і способи набуття прав. Підстави набуття прав являють собою всі юридичні факти, за наявності яких може виникнути речове право, а вже сам спосіб буде визначатись вужче за змістом і $\epsilon$ свідченням того, що йдеться саме про вольові дії учасників цивільних правовідносин.

Загалом, право сервітуту не можна надати будь-якій особі. Надання права користування річчю будь-якій особі слід трактувати як розпорядження майновим (речовим) правом. Таке розпорядження може здійснити власник на підставі договору (правочину), в тому числі розпорядчого правочину на випадок смерті - заповіту. Майнове право в такому разі не набуває правового режиму сервітуту.

Щодо заповідального відказу, то до відказоодержувача може перейти сервітутне право, що має особистий характер. Право користування житловим будинком, квартирою або іншим нерухомим чи рухомим майном є суб'єктивним речовим правом управомоченої особи. 3 іншого боку, предмет заповідального відказу у формі речового права $є$ обтяженням для власника - спадкоємця. А відказоодержувач має право вимоги до спадкоємця з часу відкриття спадщини.

Особливість житлового сервітуту полягає в тому, що його суб'єкт не має у власності житла. В нього виникає лише право користування житлом. Це право має особистісний характер. Житловий сервітут $\epsilon$ правом безоплатного користування житлом, якщо домовленістю з власником не передбачено інше. Але це не звільняє суб'єкта житлового сервітуту від обов'язку сплачувати комунальні послуги.

Отже, житловий сервітут має особисто-похідний характер від поняття сімейних відносин з власником житла. Тому існування родинно-сімейних відносин з іншими членами сім'ї, які залишилися проживати з власником житла, не $\epsilon$ підставою продовження сервітуту.

\section{Література}

1. Цивільний кодекс України : Закон України від 16 січня 2003 р. № 435-IV. URL: https:// zakon.rada.gov.ua/laws/show/435-15.

2. Постанова Пленуму Верховного Суду України від 30 травня 2008 року № 7 «Про судову практику у справах про спадкування». Вісник Верховного Суду України. 2008. № 6. Ст. 17. 
3. Земельний кодекс України : Закон України від 25 жовтня 2001 року № 2768-III. URL: https:// zakon.rada.gov.ua/laws/show/2768-14.

4. Постанова пленуму Вищого спеціалізованого суду України з розгляду цивільних і кримінальних справ від 7 лютого 2014 року № 5 «Про судову практику в справах про захист права власності та інших речових прав».

5. Лісовий кодекс України : Закон України від 21 січня 1994 № 3852-XII. URL: https:// zakon.rada.gov.ua/laws/show/3852-12.

6. Про охорону навколишнього природного середовища : Закон України від 25 червня 1991 р. № 1264-XII. Відомості Верховної Ради України. 1991. № 41. Ст. 546.

7. Житловий кодекс Української РСР. Верховна Рада Української Радянської Соціалістичної Респу- бліки. Кодекс України від 30.06.1983 № 5464-X. URL: https://zakon.rada.gov.ua/laws/show/5464-10.

8. Майданик Р.А., Скаржинський М.В. Речові права на чуже житло. Акад. прав. наук України, НДІ приват. права і підприємництва. Київ : НДІ приватного права і підприємництва АПРН України, 2006. 35 с.

9. Про свободу пересування та вільний вибір місця проживання в Україні : Закон України від 11 грудня 2003 р. № 1382-IV. Відомості Верховної Ради України. 2004. № 15. Ст. 232.

Ільків О. В., кандидат юридичних наук, доцент, доцент кафедри цивільно-правових дисциплін Міжнародного економіко-гуманітарного університету імені академіка Степана Дем'янчука 